\title{
Performance, Carcass and Meat Characteristics of West African Dwarf Rams Given Water Contaminated With Used Engine Oil
}

\author{
Eniolorunda O. O. ${ }^{1}$, Apata E. S. ${ }^{1}$, Akinruntan D. F. ${ }^{1} \&$ Tijani L. A. ${ }^{2}$ \\ ${ }^{1}$ Department of Animal Production, Olabisi Onahanjo University, Yewa Campus P.M.B. 0012, Ayetoro, Ogun \\ State, Nigeria \\ ${ }^{2}$ Department of Animal Production, Lagos State Polytechnic, Ikorodu, Lagos, Nigeria \\ Correspondence: Eniolorunda O. O., Department of Animal Production, Olabisi Onahanjo University, Yewa \\ Campus P.M.B. 0012, Ayetoro, Ogun State, Nigeria. E-mail: eniolorunda@gmail.com
}

Received: June 10, 2014 Accepted: September 28, 2014 Online Published: October 15, 2014

doi:10.5539/sar.v3n4p113 URL: http://dx.doi.org/10.5539/sar.v3n4p113

\begin{abstract}
This study was conducted to determine the effect of giving water contaminated with used engine oil on performance, carcass and meat characteristics of West African Dwarf (WAD) rams. 15 WAD rams about 10 months old were used. They were grouped into 5 balanced for weight. Used engine oil was collected from an Auto mechanic workshop in Ayetoro Yewa Ogun state and mixed to $0,5,10,15$ and $20 \mathrm{ml}$ with one litre of clean water at $0,0.5,1.0,1.5$ and $2.0 \%$ designated $\mathrm{T} 0, \mathrm{~T} 1, \mathrm{~T} 2, \mathrm{~T} 3$ and $\mathrm{T} 4$ respectively. The rams were assigned to these treatment groups in a completely randomized design experiment and were given the contaminated water for 13 weeks. Data collected were subjected to analysis of variance (ANOVA) at $p=0.05$. The results showed that nutrient intake was higher, while water intake decreased $(p<0.05)$ as the level of used engine oil in water increased, nitrogen intakes and urinary nitrogen decreased $(p<0.05)$ as well as nitrogen retention. Although weight gain increased $(p<0.05)$ feed efficiency decreased $(p<0.05)$. Carcass primal cuts and meat characteristics decreased except cooking yield and water holding capacity as used engine oil increased in the given water. It was therefore, recommended that used engine oil should not be allowed to flow freely into the surrounding water bodies where grazing animals may consume it as this may lead to reduction in their water intake which can affect the health of the animals and increased feed intake can affect profit margin of the farmers.
\end{abstract}

Keywords: carcass, meat, performance, used engine oil, west African dwarf rams

\section{Introduction}

Man, animals and plants alike need water as it is essential for their survival. The water therefore, must be free from physical chemical and microbial contamination in order to fulfill its roles.

The requirement of water is high in rearing farm animals as it must be available ad-libitum even when they are grazed or consumed feeds with high water content (Adolph, 1993). There is wide spread of water contamination in many developing countries of the world including Nigeria from different sources such as pesticides, metals, nitrates, solvents as well as used engine oil due to lack of legislation against such (CEPA, 2002). Used engine oil (UEO) is the brown to black oily liquid materials removed from internal combustion engines of vehicles after they might have been serviced (ATSDR, 1997). It contains several toxic components up to $30 \%$ aromatic hydrocarbons, with as much as $22 \mathrm{ppm}$ benzo (a) pyrene and considerable percentage of fluoranthene (EPA, 2000). It finds its way into aquatic system through run-off water and constitutes great health hazard to grazing animals as they naturally move about and drink from any water pools under extensive management system (OECD, 2000). There is dearth of information concerning the effects of used engine oil in water on the performance carcass and meet profiles of West African Dwarf (WAD) rams. This study was conducted to fill such gap.

\section{Materials and Methods}

\subsection{Test Materials}

Used engine oil (UEO) tested in this study was collected from an Auto mechanic workshop located at Ayetoro, Ogun State. Graded Levels of used engine oil at $0 \mathrm{ml}, 5.0 \mathrm{ml}, 10 \mathrm{ml} 15 \mathrm{ml}$ and $20 \mathrm{ml}$ was thoroughly mixed (v/v) with 1 litre of clean water at $0,0.5 \mathrm{~m} \mathrm{1.0,1.5}$ and 2.0\% and was designated as T0, T1,T2, T3, and T4 
respectively.

\subsection{Animals and Their Management}

15 West African Dwarf rams about 10 months old were purchased from Ayetoro market and quarantined for 15 days at small ruminant unit of the Teaching and Research Farm, College of Agricultural Sciences, Olabisi Onabanjo University. All necessary medications were given the animals, while they were fed panicum maximum at $9.00 \mathrm{am}$, concentrate feed at $3.00 \mathrm{pm}$ as well as treated water ad-libitum throughout the experimental period of 13 weeks. The composition of the experimental diet is shown on Table 1. The animals were randomly assigned into 5 experimental treatments Viz: T0, T1, T2, T3 and T4 with 3 animals per treatment balanced for weight in a completely randomized design experiment.

Table 1. Percentage composition of experimental diet

\begin{tabular}{ll}
\hline Ingredients & $\%$ \\
\hline Maize & 36.80 \\
GNC & 8.60 \\
Wheat Offal & 46.60 \\
Rice husk & 4.00 \\
Bone meal & 2.00 \\
Oyster Shell & 1.00 \\
Salt & 0.50 \\
Premix & 0.50 \\
Total & 100.00 \\
\hline
\end{tabular}

\subsection{Performance Measurement}

Live weights of rams were taken at the beginning of the experiment weekly to determine change in weight. All performance measurement were made as described by Van Soest and Robertson (1985). Feed intake was measured by subtracting the feed left over from the quantify offered to the animals on daily basis.

\subsection{Water Intake}

This was determined by measuring daily water refusal using a calibrated cylinder, this was subtracted from the quantity of water given daily.

\subsection{Feed Efficiency}

This was obtained as Average body weight/average feed intake.

\subsection{Slaughtering and Carcass Analysis}

At the end of 13 weeks of giving used engine oil contaminated water to experimental animals, 10 rams two from each treatment were randomly selected and slaughtered and carcass analysis carried out following the procedures of Okubanjo (1997).

\subsection{Dressing Percentage}

This was determined following the procedures of Aduku and Olukosi (2000) thus:

\subsection{Chilling Percentage}

$$
\text { Dressing } \%=\frac{\text { Weight of Hot Carcass }}{\text { Live weight }} \times 100
$$

This was determined as described by Apata (2011) thus:

$$
\frac{\text { Hot Carcass weight } \% \text { - Chilled carcass weight }}{\text { Hot carcass wt }} \times 100
$$

\subsection{Primal Cuts Percentage}

This was determined as described by Apata (2011) thus: 


\subsection{Primal Cut}

$$
\text { Primal cuts } \%=\frac{\text { Weight of primal cut }}{\text { Weight of Hot Carcass }} \times 100
$$

2.11 Cooking Loss, Thermal and cold shortening as well as shear force were determined following the procedures of Honikel (1998) thus

$$
\begin{gathered}
\text { Cooking loss }=\frac{\text { Initial weight of meat Final weight of meat }}{\text { Initial weight of meat }} \times 100 \\
\text { Thermal and cold shortening }=\frac{\text { Initial length of meat }- \text { Final height of meat }}{\text { Initial length of meat }} \times 100
\end{gathered}
$$

\subsection{Shear Force}

Was determined by shearing a previously boiled $10 \mathrm{~g}$ of meat from the legs of the rams at three locations using Warner - Bratzler V-notch blade shearing instrument.

\subsection{Water Holding Capacity (WHC)}

was determined following the procedures of Suzuki et al. (1991) $1 \mathrm{~g}$ of meat sample was placed between two 9 $\mathrm{cm}$ Whatman No1 filter papers (Model C. Caver hic Wabash, U.S.A). The meat samples were pressed between two $10.2 \times 10.2 \mathrm{~cm}^{2}$ plexi -glasses at about 35.2 absolute pressure for 1 minute using a vice. The meat samples were oven dried at $105^{\circ} \mathrm{C}$ for 24 hours to determine the moisture content. The amount of water released from the meat samples was measured indirectly by measuring the areas of filter papers wetted relative to the areas of pressed meat samples. Thus.

Where

$$
\mathrm{WHC}=\frac{100-\left(\mathrm{A}_{\mathrm{W}}-\mathrm{A}_{\mathrm{M}}\right) \times 9.47}{\mathrm{~W}_{\mathrm{m}}-\mathrm{M}_{\mathrm{c}}} \times 100
$$

$A_{W}=$ Area of water released from meat samples $\left(\mathrm{cm}^{2}\right)$

$\mathrm{A}_{\mathrm{m}}=$ Area of meat samples $\left(\mathrm{cm}^{2}\right)$

$\mathrm{W}_{\mathrm{m}}=$ Weight of meat samples $(\mathrm{g})$

$\mathrm{M}_{\mathrm{c}}=$ Moisture content of meat, samples (\%)

$9.47=$ constant factor.

\subsection{Chemical Analysis of Experimental Diets and Meat}

Sample of experimental diet was analysed for proximate components as described by AOAC (2002). The concentration of neutral detergent fibre (NDF), acid detergent fibre (ADF) and acid detergent Lignin (ADL) were determined using (Van Soest \& Robertson, 1985) method.

\subsection{Statistical Analysis}

All data collected were subjected to analysis of variance (ANOVA) using (SAS, 2002) at $p=0.05$. Significant differences between means were separated with Duncan's multiple range test of the same statistical analysis system.

\section{Results and Discussion}

The results of nutrient intake of WAD rams given, water contaminated with used engine oil is shown on Table 3 . There were significant $(\mathrm{p}<0.05)$ increase in dry water, organic matter, crude fibre NDF and ADF intake of the rams while only numerical increases were observed in crude protein, fat, ash and ADL intake of the animals. These results could be due to the increased level of inclusion of used engine oil in the water as the animals might need to supplement those nutrients from feed as they could be lacking in water given perhaps as a result of actions of used engine inhibiting the release of those nutrients from water. This result was in conformity with the findings of Adolph (1993) who reported that the constitution of water consumed could have serious affect on the metabolism of an animal. The same pattern of results of nutrient intake was observed in nutrient absorption by WAD rams.

In Table 4, nutrient adsorption significantly $(\mathrm{P}<0.05)$ increased as the level of used engine oil inclusion in the water given increased, only fat and ash were not significantly $(\mathrm{p}<0.05)$. This could be due to the fact that WAD 
rams given water contaminated with use engine oil might have gotten enough of those nutrient and just needed little to complement the already obs ones. Also some additives such as lubricants could have significant consequence in overall health aspect of an animal especially metabolic processes as reported by Hewstone (1994). The results of utilization by WAD rams given water contaminated with used engine oil are presented on table 5. Nitrogen intake, fecal, urinary and nitrogen balance gram/day all decrease significantly $(\mathrm{p}<0.05)$ as the level of used engine oil increased in the given water. It was higher $(p<0.05)$ in to and least $(p<0.05)$ in $T 4$. But nitrogen balance WB kg/W0.75 was higher $(\mathrm{p}<0.05)$ in TI followed by those of TO and T2 while it was least $(p<0.05)$ in T3. However, nitrogen retention was higher $(\mathrm{p}<0.05)$ rams in group T1 and T3 followed by those in T4 while those in TO retained the least $(\mathrm{p}<0.05)$ nitrogen. It was observed that restricted water intake reduced urinary nitrogen in sheep (More \& Sahni, 1985) mainly as a result of decreasing the excretion of ammonia, which did not affect nitrogen in faeces, this observation agreed with the result of this study where low urinary nitrogen was observed in sheep (rams) having higher level of used engine oil in given water probably due to the reduce voluntary water intake.

The increase nitrogen retention observed in this study might be explained on the ground that when nitrogen intake is low, output nitrogen in reduced. Performance characteristics WAD rams results are presented on Table 6 In totality forage and concentrate feed consumed by rams increased significantly $(p<0.05)$ as the level of used engine oil in given water increased. In the same vein the weight gained by the animals increased significantly as well as feed efficiency $(p<0.05)$ even though water intake by the animals decreased significantly $(p<0.05)$. These results could be due the fact that as water intake decrease caused by increased water contamination by used engine oil feed intake increased and more water might have been obtained from the feed to compensate for the reduced water intake from the source. These results corroborated the findings of Dado and Allen (1994). Carcass characteristics of WAD rams given water contaminated with used engine oil (Table 7) showed decreased in dressing percentage $(\mathrm{p}<0.05)$, carcass length, width, leg length and width as well as neck length, but there was significant $(\mathrm{p}<0.05)$ increased in percentage chilling as the level of used engine oil increased in given water. These measurements obtained for carcass commensurated with live and hot carcass weight obtained in this study and the overall results agreed with that reported by Eniolorunda and Apata (2012). Table 8 presented the results of effect of use engine oil in water on primal cuts and physical characteristics of WAD rams meat.

There were significant $(\mathrm{p}<0.05)$ decrease in primal cuts weights and percentages as the level of used engine oil increased. The same pattern of results were obtained for meat characteristics except cooking yield and WHC which decreased as the level of used engine oil increased. This could be due to overall effects of used engine oil on the water intake and nutrients absorption of the animals. The results were in agreement with the findings of Eniolorunda and Apata (2012) who reported that the higher the inclusion of used engine oil in given water the lower the cooking yield and WHC of the meat from the WAD rams.

Table 2. Chemical composition of experimental diet

\begin{tabular}{lll}
\hline Variable & $\begin{array}{l}\text { Panicum } \\
\text { Maximum (\%) }\end{array}$ & $\begin{array}{l}\text { Compounded concentrate } \\
\text { Feed (\%) }\end{array}$ \\
\hline Dry matter & 75.25 & 87.20 \\
Organic matter & 63.00 & 79.90 \\
Crude protein & 7.09 & 18.20 \\
Crude fat & 3.20 & 4.50 \\
Ash & 12.25 & 7.30 \\
NFE & 46.26 & 61.25 \\
Crude Fibre & 31.20 & 8.75 \\
NDF & 91.82 & 49.62 \\
ADF & 37.30 & 30.45 \\
ADL & 9.21 & 14.99 \\
\hline
\end{tabular}

NFE $=$ Nitrogen Free Extract; NDF $=$ Nitrogen Detergent Fibre; ADF= Acid Detergent Fibre; ADL = Acid Detergent Lignin. 
Table 3. Nutrient intake of WAD rams given water contaminated with used engine oil $\left(\mathrm{g} / \mathrm{kg} / \mathrm{W}^{0.75}\right)$

\begin{tabular}{|c|c|c|c|c|c|c|}
\hline \multicolumn{7}{|c|}{ Treatments } \\
\hline Variable & TO & T1 & $\mathbf{T} 2$ & T3 & T4 & SEM \\
\hline Dry matter & $112.34^{\mathrm{d}}$ & $113.92^{\mathrm{c}}$ & $115.65^{\mathrm{b}}$ & $115.53^{\mathrm{b}}$ & $120.67^{\mathrm{a}}$ & 30.11 \\
\hline Organic matter & $99.44^{\mathrm{e}}$ & $100.64^{\mathrm{d}}$ & $105.06^{\mathrm{c}}$ & $106.45^{\mathrm{b}}$ & $115.04^{\mathrm{a}}$ & 6.74 \\
\hline Crude protein & 18.16 & 18.35 & 18.55 & 19.04 & 19.31 & 0.63 \\
\hline Crude fat & 5.61 & 5.46 & 5.53 & 5.67 & 5.76 & 0.18 \\
\hline Ash & 13.11 & 13.29 & 13.52 & 13.89 & 14.00 & 0.49 \\
\hline NFE & $74.93^{\mathrm{c}}$ & $75.89^{c}$ & $77.13^{\mathrm{b}}$ & $78.68^{\mathrm{a}}$ & $78.97^{\mathrm{a}}$ & 3.01 \\
\hline Crude Fibre & $25.27^{\mathrm{c}}$ & $26.38^{\mathrm{b}}$ & $26.89^{\mathrm{b}}$ & $27.69^{\mathrm{ab}}$ & $28.26^{\mathrm{a}}$ & 1.56 \\
\hline NDF & $94.42^{\mathrm{e}}$ & $95.68^{\mathrm{d}}$ & $97.40^{\mathrm{c}}$ & $100.04^{\mathrm{b}}$ & $102.05^{\mathrm{a}}$ & 3.42 \\
\hline $\mathrm{ADF}$ & $46.13^{\mathrm{d}}$ & $46.34^{\mathrm{d}}$ & $47.45^{\mathrm{c}}$ & $48.61^{\mathrm{b}}$ & $49.61^{\mathrm{a}}$ & 3.66 \\
\hline $\mathrm{ADL}$ & 17.04 & 17.20 & 17.70 & 17.88 & 18.17 & 1.11 \\
\hline
\end{tabular}

abcde: Means on the same row with different superscripts are statistically significant $(\mathrm{p}<0.05)$.

NFE $=$ Nitrogen Free Extract, NDF $=$ Nitrogen Detergent Fibre.

$\mathrm{ADF}=$ Acid Detergent Fibre, $\mathrm{ADL}=$ Acid Detergent Lignuin.

Table 4. Nutrient absorbed by rams water given water contaminated with used engine oil $\left(\mathrm{g} / \mathrm{kg} / \mathrm{W}^{0.75}\right)$

\begin{tabular}{|c|c|c|c|c|c|c|}
\hline \multicolumn{7}{|c|}{ Treatments } \\
\hline Variable & TO & T1 & T2 & T3 & T4 & SEM \\
\hline Dry matter & $95.97^{b}$ & $96.23^{b}$ & $93.20^{c}$ & $106.44^{\mathrm{a}}$ & $105.79^{\mathrm{a}}$ & 7.85 \\
\hline Organic matter & $83.67^{\mathrm{c}}$ & $83.63^{\mathrm{c}}$ & $98.60^{\mathrm{a}}$ & $67.21^{\mathrm{d}}$ & $92.31^{\mathrm{b}}$ & 7.58 \\
\hline Crude protein & $15.10^{\mathrm{b}}$ & $14.67^{b}$ & $13.24^{\mathrm{c}}$ & $14.33^{\mathrm{b}}$ & 16.16 & 1.13 \\
\hline Crude fat & 5.24 & 5.01 & 4.90 & 5.11 & 5.32 & 0.21 \\
\hline Ash & 12.52 & 12.60 & 12.63 & 13.12 & 13.38 & 0.55 \\
\hline NFE & $61.16^{\mathrm{c}}$ & $61.66^{\mathrm{c}}$ & $58.98^{\mathrm{d}}$ & $64.41^{\mathrm{b}}$ & $68.67^{\mathrm{a}}$ & 4.29 \\
\hline Crude Fibre & $25.69^{b}$ & $25.45^{\mathrm{b}}$ & $25.71^{\mathrm{b}}$ & $27.14^{\mathrm{a}}$ & $27.40^{\mathrm{a}}$ & 1.65 \\
\hline NDF & $87.79^{\mathrm{d}}$ & $87.52^{\mathrm{d}}$ & $92.57^{\mathrm{b}}$ & $90.89^{c}$ & $94.85^{\mathrm{a}}$ & 5.61 \\
\hline $\mathrm{ADF}$ & $40.43^{c}$ & $59.00^{\mathrm{a}}$ & $39.36^{\mathrm{d}}$ & $40.54^{\mathrm{c}}$ & $44.15^{\mathrm{b}}$ & 11.05 \\
\hline $\mathrm{ADL}$ & $11.89^{c}$ & $17.14^{\mathrm{a}}$ & $10.90^{\mathrm{c}}$ & $11.30^{\mathrm{c}}$ & $12.46^{\mathrm{b}}$ & 3.67 \\
\hline
\end{tabular}

abcd: Means on the same row with different superscripts are statistically significant $(\mathrm{p}<0.05)$

$\mathrm{NFE}=$ Nitrogen Free Extract, NDF $=$ Neutral Detergent firbe.

$\mathrm{ADF}=$ Acid Detergent Fibre, $\mathrm{ADL}=$ Acid Detergetn Lignin. 
Table 5. Nitrogen Utilization by WAD rams given water contaminated with used engine oil $\left(\mathrm{g} / \mathrm{kg} / \mathrm{W}^{0.75}\right)$

\begin{tabular}{lllllll}
\hline \multirow{2}{*}{ Variable } & \multicolumn{9}{c}{ Treatments } & \multicolumn{2}{c}{} \\
\hline Nitrogen intake & TO & T1 & T2 & T3 & T4 & SEM \\
Faecal nitrogen & $11.59^{\mathrm{a}}$ & $9.99^{\mathrm{b}}$ & $10.20^{\mathrm{b}}$ & $6.49^{\mathrm{c}}$ & $7.12 \mathrm{c}$ & 0.51 \\
Urinary Nitrogen & 1.59 & 1.43 & 1.82 & 0.95 & 0.95 & 0.34 \\
Nitrogen bal.g/day & $4.38^{\mathrm{a}}$ & $1.90^{\mathrm{c}}$ & $2.84^{\mathrm{b}}$ & $1.21^{\mathrm{c}}$ & $1.59^{\mathrm{c}}$ & 0.96 \\
Nitrogen bal WB kg/ ${ }^{0.75}$ & $7.46^{\mathrm{a}}$ & $6.67^{\mathrm{a}}$ & $5.55^{\mathrm{b}}$ & $4.34^{\mathrm{c}}$ & $4.49^{\mathrm{c}}$ & 1.62 \\
Nitrogen retention & $0.82^{\mathrm{b}}$ & $0.93^{\mathrm{a}}$ & $0.83^{\mathrm{b}}$ & $0.66^{\mathrm{d}}$ & $0.70^{\mathrm{c}}$ & 0.15 \\
\hline
\end{tabular}

abcd: Means on the same row with different superscripts are statistically significant $(\mathrm{p}<0.05)$.

Table 6. Performance characteristics of WAD rains given water contaminated with used engine oil $\left(\mathrm{g} / \mathrm{kg} / \mathrm{W}^{0.75}\right)$

\begin{tabular}{|c|c|c|c|c|c|c|}
\hline \multicolumn{7}{|c|}{ Treatments } \\
\hline Variable & TO & T1 & $\mathbf{T 2}$ & T3 & T4 & SEM \\
\hline Forage/head/day & $428.08^{\mathrm{e}}$ & $429.80^{\mathrm{d}}$ & $435.37^{\mathrm{c}}$ & $539.37^{b}$ & $447.61^{\mathrm{a}}$ & 5.72 \\
\hline Concentrate feed & $521.47^{\mathrm{a}}$ & $521.09^{\mathrm{a}}$ & $517.63^{\mathrm{b}}$ & $521.28^{\mathrm{a}}$ & $521.24^{\mathrm{a}}$ & 6.88 \\
\hline Total & $949.55^{\mathrm{e}}$ & $950.04^{\mathrm{d}}$ & $953.38^{\mathrm{c}}$ & $960.61^{\mathrm{b}}$ & $968.88^{\mathrm{a}}$ & 10.42 \\
\hline Initiative $\mathrm{wt}(\mathrm{kg})$ & 8.80 & 8.40 & 8.50 & 8.40 & 8.40 & 0.15 \\
\hline Final live wt (kg) & 16.17 & 16.45 & 17.00 & 17.50 & 17.50 & 0.65 \\
\hline Weight gain $(\mathrm{kg})$ & $7.77^{\mathrm{b}}$ & $9.05^{\mathrm{a}}$ & $8.50^{\mathrm{ab}}$ & $9.00^{\mathrm{a}}$ & $9.30^{\mathrm{a} "}$ & 0.65 \\
\hline Ave. daily wt gain $(\mathrm{kg})$ & $111.00^{\mathrm{e}}$ & $115.00^{\mathrm{d}}$ & $121.00^{\mathrm{c}}$ & $130.00^{\mathrm{b}}$ & $132.50^{\mathrm{a}}$ & 3.37 \\
\hline Metabolic wt. gain $\left(\mathrm{kg} / \mathrm{W}^{0.75}\right)$ & 6.57 & 6.62 & 6.75 & 6.83 & 6.91 & 0.16 \\
\hline Feed efficiency & $0.117^{\mathrm{e}}$ & $0.121^{\mathrm{d}}$ & $0.127^{\mathrm{c}}$ & $0.125^{\mathrm{b}}$ & $0.137^{\mathrm{a}}$ & 0.009 \\
\hline Water intake (g/day) & $1273.71^{\mathrm{a}}$ & $883.43^{\mathrm{b}}$ & $806.41^{\mathrm{c}}$ & $776.45^{\mathrm{d}}$ & $748.10^{\mathrm{e}}$ & 0.98 \\
\hline Water intake $(\mathrm{g} / \mathrm{kg} / \mathrm{w} 0.75$ & $193.87^{\mathrm{a}}$ & $133.45^{\mathrm{b}}$ & $119.47^{\mathrm{c}}$ & $112.44^{\mathrm{d}}$ & $108.26^{\mathrm{e}}$ & 20.25 \\
\hline $\begin{array}{l}\text { Used engine oil intake } \\
\text { (ml.UEO) }\end{array}$ & $0.00^{\mathrm{e}}$ & $4.42^{\mathrm{d}}$ & $8.06^{\mathrm{c}}$ & $11.52^{\mathrm{b}}$ & 14.96 & 3.80 \\
\hline
\end{tabular}

Table 7. Carcass characteristics of WAD rams given water contaminated with used engine oil $\left(\mathrm{g} / \mathrm{kg} / \mathrm{W}^{0.75}\right)$

\begin{tabular}{lllllll}
\hline \multirow{2}{*}{ Variable } & \multicolumn{7}{c}{ Treatments } & \multicolumn{2}{c}{} \\
\hline Live Weight (kg) & TO & T1 & T2 & T3 & T4 & SEM \\
Hot carcass wt (kg) & 8.80 & 8.40 & 8.50 & 8.40 & 8.40 & 0.15 \\
Dressing (\%) & 7.78 & 7.35 & 7.47 & 7.36 & 7.34 & 0.17 \\
Chilled carcass wt (kg) & $88.41^{\mathrm{a}}$ & $87.50^{\mathrm{ab}}$ & $87.88^{\mathrm{ab}}$ & 87.62 & $87.38^{\mathrm{b}}$ & 6.72 \\
Chilling (\%) & 7.75 & 7.32 & 7.43 & 7.31 & 7.28 & 0.19 \\
Carcass length (cm) & $0.26^{\mathrm{e}}$ & $0.41^{\mathrm{d}}$ & $0.54^{\mathrm{c}}$ & $0.68^{\mathrm{b}}$ & $0.82^{\mathrm{a}}$ & 0.10 \\
Carcass width (cm) & $56.20^{\mathrm{a}}$ & $55.17^{\mathrm{b}}$ & $54.12^{\mathrm{c}}$ & $53.10^{\mathrm{d}}$ & $50.17^{\mathrm{e}}$ & 0.93 \\
Leg length (cm) & $22.73^{\mathrm{a}}$ & $22.20^{\mathrm{a}}$ & $22.20^{\mathrm{a}}$ & $22.00^{\mathrm{a}}$ & $18.30^{\mathrm{b}}$ & 0.29 \\
Leg Width (cm) & $25.63^{\mathrm{a}}$ & $25.17^{\mathrm{a}}$ & $24.10^{\mathrm{b}}$ & $21.17^{\mathrm{c}}$ & $20.12^{\mathrm{d}}$ & 0.45 \\
Neck length $(\mathrm{cm})$ & $17.20^{\mathrm{a}}$ & $15.70^{\mathrm{b}}$ & $14.65^{\mathrm{c}}$ & $14.20^{\mathrm{c}}$ & $12.24^{\mathrm{d}}$ & 0.63 \\
\hline
\end{tabular}

abcd: Means on the same row with different superscripts are statistically significant $(\mathrm{p}<0.05)$. 
Table 8. Primal cuts and Meat characteristics of WAD rains given water contaminated with used engine oil ( $\mathrm{g} / \mathrm{kg}$ $\left./ \mathrm{W}^{0.75}\right)$

\begin{tabular}{|c|c|c|c|c|c|c|}
\hline \multicolumn{7}{|c|}{ Treatments } \\
\hline Variable & TO & T1 & $\mathbf{T 2}$ & T3 & T4 & SEM \\
\hline \multicolumn{7}{|l|}{ Primal Cut } \\
\hline Chilled carcass wt (kg) & 7.76 & 7.32 & 7.43 & 7.31 & 7.28 & 0.19 \\
\hline Leg weight (kg) & 1.05 & 1.00 & 1.03 & 1.01 & 0.97 & 0.08 \\
\hline Leg weight (\%) & 13.53 & 13.66 & 13.86 & 13.82 & 13.32 & 0.29 \\
\hline Shoulder wt (kg) & $0.48^{\mathrm{a}}$ & $0.45^{\mathrm{b}}$ & $0.42^{\mathrm{c}}$ & $0.40^{\mathrm{d}}$ & $0.37^{\mathrm{e}}$ & 0.02 \\
\hline Shoulder \% & $6.19^{\mathrm{a}}$ & $6.15^{\mathrm{a}}$ & $5.65^{\mathrm{ab}}$ & $5.47^{\mathrm{ab}}$ & $5.08^{\mathrm{b}}$ & 0.24 \\
\hline Loln wt (kg) & $0.35^{\mathrm{a}}$ & $0.29^{\mathrm{e}}$ & $0.34^{\mathrm{b}}$ & $0.30^{\mathrm{d}}$ & 0.31 & 0.5 \\
\hline Loln $(\%)$ & 4.51 & 3.96 & 4.58 & 4.10 & 4.25 & 0.26 \\
\hline Rack wt (kg) & $0.41^{\mathrm{b}}$ & $0.40^{\mathrm{c}}$ & $0.42^{\mathrm{a}}$ & $0.39^{\mathrm{d}}$ & $0.37 \mathrm{e}$ & 0.09 \\
\hline Rack (\%) & 5.28 & 5.46 & 5.65 & 5.34 & 5.08 & 0.28 \\
\hline Breast wt (kg) & $0.46^{\mathrm{b}}$ & $0.45^{\mathrm{c}}$ & $0.51^{\mathrm{a}}$ & $0.42^{\mathrm{d}}$ & $0.40^{\mathrm{e}}$ & 0.03 \\
\hline Breast (\%) & $5.93^{\mathrm{b}}$ & $6.15^{\mathrm{ab}}$ & $6.86^{\mathrm{a}}$ & $5.75^{\mathrm{b}}$ & $5.49^{\mathrm{b}}$ & 0.21 \\
\hline Neck wt(kg) & $0.56^{\mathrm{a}}$ & $0.51^{\mathrm{d}}$ & $0.54^{\mathrm{b}}$ & $0.53^{\mathrm{c}}$ & 0.50 & 0.01 \\
\hline Neck $(\%)$ & 7.21 & 6.97 & 7.23 & 7.11 & 6.87 & 0.15 \\
\hline \multicolumn{7}{|l|}{ Meat } \\
\hline Cooking loss (\%) & $17.37^{\mathrm{d}}$ & $20.03^{\mathrm{c}}$ & $21.18^{\mathrm{b}}$ & $22.00^{\mathrm{b}}$ & $23.45^{\mathrm{a}}$ & 2.83 \\
\hline Cooking yield (\%) & $82.63^{\mathrm{a}}$ & $79.97^{\mathrm{b}}$ & $78.82^{\mathrm{c}}$ & $78.00^{\mathrm{c}}$ & $76.55^{\mathrm{d}}$ & 0.01 \\
\hline Thermal shortening (\%) & $18.20^{\mathrm{c}}$ & $21.04^{\mathrm{b}}$ & $21.20^{\mathrm{b}}$ & $22.10^{\mathrm{a}}$ & $22.30^{\mathrm{a}}$ & 2.85 \\
\hline Cold shortening (\%) & $11.81^{\mathrm{c}}$ & $16.71^{\mathrm{b}}$ & $18.32^{\mathrm{ab}}$ & $19.01^{\mathrm{a}}$ & $19.43^{\mathrm{a}}$ & 1.47 \\
\hline Shear force $(N)$ & $2.00^{\mathrm{b}}$ & $2.05^{\mathrm{b}}$ & $2.15^{\mathrm{b}}$ & $3.19^{\mathrm{a}}$ & $3.25^{\mathrm{a}}$ & 0.05 \\
\hline WHC (\%) & $68.25^{\mathrm{a}}$ & $64.80^{\mathrm{b}}$ & $62.00^{\mathrm{c}}$ & $61.35^{\mathrm{d}}$ & $60.71^{\mathrm{d}}$ & 0.84 \\
\hline
\end{tabular}

abcde: Means on the same row with different superscripts are statistically significant $(\mathrm{P}<0.05)$.

WHC $=$ Water Holding Capacity .

\section{Conclusion}

It can be concluded from the results of this study that used engine oil had serious effect on performance, carcass and meat profiles of WAD rams. This was because less water was consumed by the animals which led to consumption of more feed which apparently compensated the water needs of the animal that culminated in reduced carcass and meat quality attributes of the rams. It is therefore, suggested that used engine oil should not be allowed to flow freely into the surrounding water bodies so that grazing animals may not consume it as this will reduce their water intake and consequently increase feed intake which can be very costly to the farmers as it may affect both the health of the animals as well as the profit margin of the farmers.

\section{References}

Adolph, E. F. (1983). The metabolism and distribution of water body tissues. Physiol. Rev, 13, 336-371.

Aduku, A. O., \& Olukosi, J. O. (2000). Animal Product Possessing and Handling in the Tropics. Living Books Series (pp. 24-32). GU Publication, Abuja, Nigeria.

AOAC. (2000). Official Methods of Analysis (19th ed.), (p. 1219). Washington, D.C.: AOAC International Inc.

Apata, E. S. (2011). Quality attributes of Red Sokoto buck meat as influenced by post-slaughter processing methods. Ph.D Thesis in the Department of Animal Science University of Ibadan, Nigeria.

ATSDR. (1997). Toxicological Profile of used mineral -based crack case oil. Agency for Toxic Substances and Diseases Registry, Public Health Service, United States Department of Health and Human Services Atlanta, 
Georgia, U.S.A.

CEPA. (2002). Waste/used crack case oil follow-up report on the substance for which there was insufficient information to include it constitutes a danger ot the environmental Protection Act. Canada.11

Dado, R. G., \& Allen, M. S. (1994). Variation and relationship among feeding chewing and drinking variables for lactating dairy cows. J. Diary Sci., 77, 132. http://dx.doi.org/10.3168/jds.S0022-0302 (94)76936-8

Eniolorunda, O. O., \& Apata, E. S. (2012). Effect of feeding sub-chronic contaminated water with graded levels of used engine oil on carcass and meat quality of West African Dwarf rams In II. Bitto, F. G. Kaankuka \& S. Attah Sustainable Animal Production for National Food Security and Poverty Alleviation Proc. of Nig. Soc. Animal production $37^{\text {th }}$ Ann. Conference Makardi Benue State $18^{\text {th }}-21^{\text {st }}$ March pp. $464-465$.

EPA. (2000). Standard practise for the toxicity testing of lubricants. Sample preparation and results interpretation. Environmental protection Agency EM 21393, 1627, 9.1, 16-21.

Hewstone, R. K. (1994). Environmental Health Aspects of Lubricant additives. The science of the Environment, $156,243-254$

Honikel, J. L. (1988). Reference Methods for the assessment of physical characteristics of meat. Meat Sci., 49, 447-457. http://dx.doi.org/10.1016/S0309-1740 (98)00034-5

More, T., \& Sahni, K. L. (1985). Effect of Water intake on feed digestibility. World view of Animals production Vol. xvii No.2

OECD. (2000). Guidance Notes for the analysis and evaluation of repeat dose toxicity studies. Environment, Health and Safety publication series on testing and assessment. Environment Directorate Paris p. 2772.

Okubanjo, A. O. (1997). Meat characteristics of singed and conventionally dressed cheron carcasses. J. Food Sci. Technol, 34(6), 494-497.

SAS. (2002). Statistical Analysis System.SAS Stat. Version 9 SAS Institute Inc. Garry NC; USA.

Suzuki, A., Kaima, N., \& Ikeuchi, Y. (1991). Carcass composition and meat quality of Chinese purebred and European X Chinese crossbred pigs. Meat sci, 29.

Van Soest, P. J., \& Robertson, J. B. (1985). Analysis of forage and fibrous food. A laboratory manual for Animal Science 613 Cornel Univeristy, Ithaca, NY, U.S.A.

\section{Copyrights}

Copyright for this article is retained by the author(s), with first publication rights granted to the journal.

This is an open-access article distributed under the terms and conditions of the Creative Commons Attribution license (http://creativecommons.org/licenses/by/3.0/). 